\title{
Relaxing effect of eugenol and essential oils in Pomacea canaliculata
}

\author{
Adriane Erbice Bianchini ${ }^{1}$ Jessyka Arruda da Cunha ${ }^{1}$ Isabel Cristina Markowski Brusque ${ }^{1}$ \\ Carlos Garrido Pinheiro ${ }^{2}$ Bianca Schindler ${ }^{2}$ Berta Maria Heinzmann $^{3}$ Bernardo Baldisserotto $^{1,4^{*}}$ \\ ${ }^{1}$ Departamento de Fisiologia e Farmacologia, Universidade Federal de Santa Maria (UFSM), Santa Maria, RS, Brasil. \\ ${ }^{2}$ Departamento de Engenharia Florestal, Universidade Federal de Santa Maria (UFSM), Santa Maria, RS, Brasil. \\ ${ }^{3}$ Departamento de Farmácia Industrial, Universidade Federal de Santa Maria (UFSM), Santa Maria, RS, Brasil. \\ ${ }^{4}$ Programa de Pós-graduação em Zootecnia, Universidade Federal de Santa Maria (UFSM), 97105-900, Santa Maria, RS, Brasil. E-mail: \\ bbaldisserotto@hotmail.com. ${ }^{*}$ Corresponding author.
}

\begin{abstract}
This study evaluated the potential relaxing and/or molluscicidal effects of eugenol and essential oils of Origanum majorana, Ocimum americanum, Hesperozygis ringens, and Piper gaudichaudianum in the gastropod Pomacea canaliculata. Compounds were tested at concentrations of 100, 250,500, and $750 \mu \mathrm{L} \mathrm{L} \mathrm{L}^{-1}$ to evaluate the relaxing effects. In the second experiment, animals were exposed to 10, 25 , and $50 \mu L L^{-1}$ of essential oils of $H$. ringens and P. gaudichaudianum for a period of $24 \mathrm{~h}$ for the evaluation of molluscicidal effects. Eugenol and essential oils of $O$. majorana and $O$. americanum showed relaxing effects at $\geq 250 \mu L L^{-1}$, but the essential oils of $H$. ringens and $P$. gaudichaudianum did not promote relaxing or molluscicidal effects within the times and concentrations studied. Therefore, only eugenol and the essential oils of $O$. majorana and $O$. americanum can be used for relaxation purposes in $P$. canaliculata.

Key words: anesthesia, golden apple snail, mollusk, Ocimum americanum, Origanum majorana.
\end{abstract}

Efeito relaxante de eugenol e óleos essenciais em Pomacea canaliculata

RESUMO: Este estudo teve como objetivo avaliar os possiveis efeitos relaxantes elou moluscicidas do eugenol e óleos essenciais de Origanum majorana, Ocimum americanum, Hesperozygis ringens e Piper gaudichaudianum no gastrópode Pomacea canaliculata. Os compostos foram testados nas concentrações de 100, 250, 500 e $750 \mu \mathrm{L} \mathrm{L}^{-1}$ para avaliar os efeitos relaxantes. Em um segundo experimento, os animais foram expostos a 10, 25 e 50 $\mu L_{L}^{-1}$ por 24 horas aos óleos essenciais de $H$. ringens e P. gaudichaudianum para avaliação dos efeitos moluscicida. $O$ eugenol e os óleos essenciais de $O$. majorana e $O$. americanum apresentaram efeito relaxante nas concentrações $\geq 250 \mu \mathrm{L} \mathrm{L}{ }^{-1}$, mas os óleos essenciais de H. ringens e P. gaudichaudianum não promoveram efeito relaxante ou moluscicida no tempo e concentrações estudadas. Portanto, apenas o eugenol e os óleos essenciais de O. majorana e O. americanum podem serem usados para fins de relaxamento em $P$. canaliculata.

Palavras-chave: caracol maçã-dourada, moluscos, anestesia, Origanum majorana, Ocimum americanum.

\section{INTRODUCTION}

Many mollusk species have economic importance, such in the production of pearls or in research (AQUILINA \& ROBERTS, 2000; WYETH et al., 2009). Anesthetic substances have been used to improve their breeding in captivity (GARR et al., 2012), minimizing unpleasant sensations that these animals are likely to experience in handling and surgeries (COOPER, 2011), facilitating pearl withdrawal in bivalves (AQUILINA \& ROBERTS, 2000). Almost all anesthetic substances used in shellfish are synthetic products such as benzocaine, MS-222 and 2-phenoxyethanol, and the minority are plant extractives (GARR et al., 2012). Essential oils (EOs) of Lippia alba and Aloysia triphylla (PARODI et al., 2012), for example, and isolated substances such as eugenol (GOMES et al., 2011; PARODI et al., 2012) and linalool (HELDWEIN et al., 2014) are effective to anesthetize fish and shrimps. Thus, we can assume that EOs may also be effective in mollusks.

Although some shellfish species have economic importance, others, such as Pomacea canaliculata, have become pests in agriculture and aquaculture because they are highly invasive and difficult to eliminate or control biologically (HAYES et al., 2015). In addition, they serve as intermediate hosts of disease-causing human parasites (SONG et al., 2016). Pomacea canaliculata is a gastropod 
from the family Ampullariidae, popularly known as golden apple snail. The uncontrolled spread of these gastropods has increased the demand for preventive and control measures through products that are non-toxic to other non-target organisms and the environment, as synthetic products used for this purpose have high residual effects (CALUMPANG et al., 1995). Products extracted from plants are promising alternatives because they are biodegradable and from renewable sources; they also have fewer adverse effects on the ecosystem. There are studies reporting molluscicidal activity of some plant extracts against $P$. canaliculata (DAI et al., 2011; KIJPRAYOON et al., 2014) and other mollusk species (RODRIGUES et al., 2013; HAMED et al., 2015). In this context, the aim of this study was to evaluate possible molluscicidal and/or relaxing effects of eugenol and the EOs of Origanum majorana, Ocimum americanum, Hesperozygis ringens, and Piper gaudichaudianum on $P$. canaliculata.

\section{MATERIALS AND METHODS}

The animals were obtained from earth ponds in a fish culture in São João do Polêsine city (Rio Grande do Sul, Brazil) and housed in the Fish Physiology Laboratory at the Universidade Federal de Santa Maria (UFSM) under the following conditions: temperature $19.02 \pm 0.02^{\circ} \mathrm{C}, \mathrm{pH} 7.85 \pm 0.01$, and dissolved oxygen levels $8.59 \pm 0.25 \mathrm{mg} \mathrm{L}^{-1}$. Identification of specimens was carried out by Dr. Carla Bender Kotzian (Department of Biology, UFSM).

\section{Essential oils and isolated substance}

Eugenol and the EO of leaves of $O$. majorana were purchased from Sigma-Aldrich, Brazil, and Vimontti ${ }^{\circledR}$ (Agroindústria São Caetano Ltda, Brazil), respectively. The other plant species $(O$. americanum, $H$. ringens, and $P$. gaudichaudianum) were collected in São João do Polêsine, São Francisco de Assis, and Santa Maria cities, Rio Grande do Sul State, respectively. The EOs were obtained from the aerial parts of the plants by hydrodistillation using a Clevenger apparatus for $2 \mathrm{~h}$ and subsequently stored in amber glasses at $-4^{\circ} \mathrm{C}$ in the dark prior to phytochemical analysis (EUROPEAN PHARMACOPOEIA, 2007).

\section{Phytochemical analysis}

Characterization of EOs was performed by chromatographic analysis using an Agilent 7890A gas chromatograph coupled to an Agilent 5975C mass selective detector (GC-MS). The identification of constituents was achieved by the comparison of retention indices, obtained by the use of a calibration curve of n-alkanes injected at the conditions mentioned for the samples, and the mass fragmentation patterns with the data of ADAMS (2009), NIST (2010), VIEIRA et al. (2014), and PINHEIRO et al. (2016).

\section{Induction of relaxation and recovery}

Animals $(11.87 \pm 0.76 \mathrm{~g})$ were placed in continuously aerated 1-L aquaria ( $\mathrm{n}=$ five animals/ aquarium) in duplicate. Compounds and EOs previously dissolved in 95\% ethanol (1:10) were tested at concentrations of $100,250,500$, and $750 \mu \mathrm{L}$ $\mathrm{L}^{-1}$. Control experiments were performed using aquaria containing only ethanol at a concentration equivalent to the highest dilution used for samples. The evaluation of relaxation was based on the experimental protocol described by GARR et al. (2012), with some adjustments. The maximum evaluation time was $40 \mathrm{~min}$, with the percentage of relaxed animals registered every $10 \mathrm{~min}$. Animals were considered relaxed when they did not show any resistance to the pulling of the operculum with the aid of a forceps. After relaxation, animals were transferred to anesthetic-free aquaria. Recovery time was evaluated at $10 \mathrm{~min}$ intervals and the animal was considered recovered when it presented resistance to pulling of the operculum. Integrity and mortality were evaluated 24 hours after the experiment.

\section{Molluscicidal effect}

An additional experiment was performed with gastropods exposed to 10,25 , or $50 \mu \mathrm{L} \mathrm{L}^{-1}$ of the EOs of $H$. ringens and $P$. gaudichaudianum, which revealed toxicity in the first experiment. The animals were placed in 1-L aquaria ( $\mathrm{n}=$ five animals aquarium ${ }^{-1}$, in duplicate) with each EO previously solubilized in $95 \%$ ethanol (1:10). A control group (water only) and another exposed to ethanol $\left(450 \mu \mathrm{L} \mathrm{L}^{-1}\right)$ were also observed. Mortality and integrity of animals were evaluated after 24 hours.

\section{Statistical analysis}

Data were submitted to Levene's test to determine homogeneity of variances, after which one-way ANOVA was performed, followed by Tukey's test or Kruskal-Wallis test, when appropriate. The tests were performed using the software package Statistica (version 11.0). The effective concentration that relaxes $50 \%$ of the animals $\left(\mathrm{EC}_{50}\right)$ was calculated with the SigmaPlot software. The minimum significance level was 95\% $(\mathrm{P}<0.05)$. Data are reported as means $\pm \mathrm{SEM}$. 


\section{RESULTS}

\section{Chemical composition of essential oils}

The EOs presented as major constituents the following compounds: terpinen-4-ol $(29.13 \%)$, $\gamma$-terpinene $(17.99 \%)$, and $\alpha$-terpinene $(9.72 \%)$ in the EO of $O$. majorana; dillapiole $(84.32 \%)$ in the EO of $P$. gaudichaudianum; eucalyptol (24.31\%), linalool $(23.44 \%)$, and eugenol $(14.86 \%)$ in the EO of $O$. americanum; and pulegone $(74.27 \%)$ in the $\mathrm{EO}$ of $H$. ringens.

\section{Induction of relaxation and recovery}

Ethanol did not show any relaxing effect on animals within the time frame of the analysis. Essential oils, as well as eugenol, did not promote relaxation at $100 \mu \mathrm{L} \mathrm{L}^{-1}$, but the EOs of $O$. americanum and $O$. majorana and eugenol promoted relaxation at concentrations above $100 \mu \mathrm{L} \mathrm{L}^{-1}$. Use of $250 \mu \mathrm{L} \mathrm{L}^{-1}$ eugenol induced relaxation of only $40 \%$ of the animals, but most animals relaxed at higher concentrations. The EO of $O$. americanum had a higher percentage of relaxed animals $(70 \%)$ at $250 \mu \mathrm{L} \mathrm{L}^{-1}$, with the effect decreasing to $50 \%$ with increasing concentrations. In contrast, the two lowest concentrations ( 250 and $500 \mu \mathrm{L} \mathrm{L}^{-1}$ ) of EO of $O$. majorana relaxed only $10 \%$ of the animals, while at $750 \mu \mathrm{L} \mathrm{L}^{-1}, 80 \%$ of the animals relaxed (Figure $1 \mathrm{~A}$ ). Other EOs tested (P. gaudichaudianum and H. ringens) did not promote relaxation, but caused a loss of mucus in the animals at all concentrations tested. There was no significant difference between the relaxation time in the concentrations of eugenol and $\mathrm{EO}$ of $O$. americanum. It was not possible to perform statistical analysis of the relaxation time between the different concentrations of the EO of O. majorana because of the small number of animals that relaxed (Figure $1 \mathrm{~B}$ ). The $\mathrm{EC}_{50}$ of eugenol and the $\mathrm{EO}$ of $O$. majorana were 269.5 and $662.1 \mu \mathrm{L} \mathrm{L}^{-1}$, respectively. The $\mathrm{EC}_{50}$ of the $\mathrm{EO}$ of $O$. americanum could not be calculated because no significant relationship concentration-response was reported.

The percentage of recovered animals exposed to eugenol was not related to concentration. Mollusks exposed to the highest concentration of the EO of $O$. americanum presented a higher percentage of recovery, and the few specimens exposed to all concentrations of the EO of $O$. majorana that relaxed showed recovery within the observation time (Figure 1C). Recovery time was not significantly affected by eugenol concentration. Low number of animals that recovered from the exposure to the EOs did not allow a statistical analysis of this parameter (Figure 1D).

Eugenol and the EOs of $O$. americanum and O. majorana did not cause mortality after
24 hours; however, the EOs of $H$. ringens and $P$. gaudichaudianum at $750 \mu \mathrm{L} \mathrm{L}^{-1}$ provoked 20 and $30 \%$ mortality, respectively. Other animals exposed to $P$. gaudichaudianum and $H$. ringens and remained alive exhibited fragile and brittle shells.

\section{Molluscicidal effect}

No mortality was observed in any of the treatments after $24 \mathrm{~h}$, but gastropods exposed to $50 \mu \mathrm{L}$ $\mathrm{L}^{-1}$ of both EOs tested showed damages in their shells, as reported in the previous experiment.

\section{DISCUSSION}

Eugenol and the EOs of $O$. americanum and $O$. majorana promoted muscle relaxation in $P$. canaliculata. This effect was expected, since these compounds have an anesthetic effect in fish (GOMES et al., 2011, SILVA et al., 2015; CUNHA, et al., 2017). Eugenol also presented anesthetic activity in crustaceans (PARODI et al., 2012). In gastropods, clove oil at $350 \mu \mathrm{L} \mathrm{L}^{-1}$ showed $100 \%$ efficacy in relaxing Pomacea paludosa within about 20min (GARR et al., 2012), while eugenol, the main constituent of clove oil, was $100 \%$ effective in the present study at relaxing $P$. canaliculata only at a higher concentration $\left(750 \mu \mathrm{L} \mathrm{L}^{-1}\right)$ and with a longer exposure time. Animals required less time to recover from eugenol exposure, but only $40 \%$ of the animals that relaxed with $750 \mu \mathrm{L} \mathrm{L}^{-1}$ recovered within the observation period. The intermediate concentration of eugenol tested $\left(500 \mu \mathrm{L} \mathrm{L}^{-1}\right)$ showed the best result, with $100 \%$ animals recovered.

The EO of $O$. americanum presented as major constituents eucalyptol, linalool, and eugenol, corroborating the results reported by SILVA et al. (2015). The relaxing effect of this oil can be attributed to eugenol, which has been proven to have a relaxing effect in $P$. canaliculata, and linalool, which also has an anesthetic effect on silver catfish, Rhamdia quelen (HELDWEIN et al., 2014). In contrast, eucalyptol showed no anesthetic activity up to $17 \mathrm{mg} \mathrm{L}^{-1}$ when tested in this species (HELDWEIN, 2011), but was effective in blocking the excitability of the superior cervical ganglion neurons of in vitro rats (FERREIRA-DA-SILVA et al., 2009). Most likely, the relaxing effect of the EO of $O$. americanum is due to the synergistic action of its compounds. Regarding efficacy, it was possible to relax $70 \%$ of the animals at $250 \mu \mathrm{L} \mathrm{L}^{-1}$ within $30 \mathrm{~min}$, whereas higher concentrations had lower efficacy; although, there was no difference in relaxation time. Similar results were obtained for Ostrea edulis anesthetized with urethane and menthol; namely, lower concentrations were more effective (CULLOTY \& MULCAHY, 1992). 


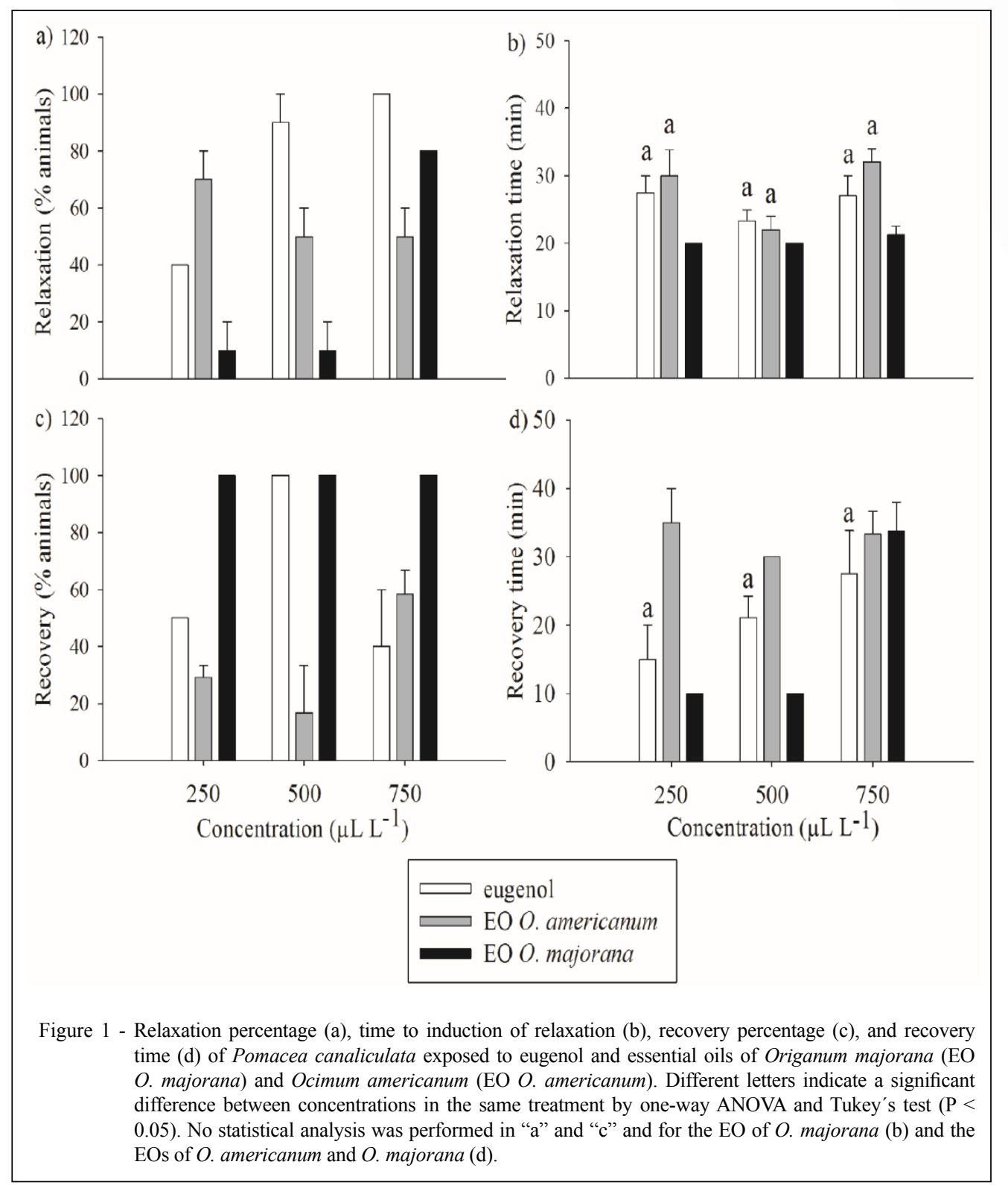

Terpinen-4-ol, $\gamma$-terpinene, and $\alpha$-terpinene were the main constituents identified in the EO of O. majorana. This same EO presented anesthetic activity in silver catfish at concentrations $\geq 100 \mu \mathrm{L} \mathrm{L}^{-1}$ (CUNHA, et al., 2017). In P. canaliculata, the relaxing effect was obtained from $250 \mu \mathrm{L} \mathrm{L}^{-1}$ (10\% efficacy), but only produced a satisfactory effect at a higher concentration $\left(750 \mu \mathrm{L} \mathrm{L}^{-1}\right)$. However, all animals that relaxed with EO of $O$. majorana recovered up to $40 \mathrm{~min}$. High concentrations of nembutal $\left(1,000 \mu \mathrm{L} \mathrm{L}^{-1}\right)$ and 2-phenoxyethanol $\left(3,000 \mu \mathrm{L} \mathrm{L}^{-1}\right)$ were also necessary for the relaxation of Haliotis iris (AQUILINA \& ROBERTS, 2000) and Pomacea paludosa (GARR et al., 2012), respectively.

The EOs of $H$. ringens and $P$. gaudichaudianum at concentrations of up to $750 \mu \mathrm{L} \mathrm{L}^{-1}$ did not cause muscle relaxation in the golden apple snail. The $\mathrm{EO}$ of $H$. ringens promoted deep anesthesia (111 to $\left.554 \mu \mathrm{LL}^{-1}\right)$ without mortality in silver catfish (SILVA et al., 2013), and its effect was attributed to the presence of pulegone (96.66\%), an allosteric modulator of GABA (TONG \& COATS, 2010). As GABA immunoreactive neurons are reported in the central nervous 
system of gastropods (HATAKEYAMA \& ITO, 2000; GUNARATNE et al., 2014; 2016), this result was unexpected.

Pomacea canaliculata can cause losses in agriculture (COWI, 2002) and public health problems because it is an intermediate host of the nematode Angiostrongylus cantonensis, responsible for causing meningitis in humans (SONG et al., 2016). For this reason, the molluscicidal activity of the EOs of $H$. ringens and $P$. gaudichaudianum were tested. Both EOs did not cause mortality within $24 \mathrm{~h}$ exposure at the lower tested concentrations $\left(10,25\right.$, and $\left.50 \mu \mathrm{L} \mathrm{L}^{-1}\right)$, but loss of mucus and degradation of the calcareous shell were observed. However, as $750 \mu \mathrm{L} \mathrm{L}^{-1}$ of both EOs provoked $20-30 \%$ mortality within $40 \mathrm{~min}$, it is likely that the $100-750 \mu \mathrm{L} \mathrm{L}^{-1}$ range would induce $100 \%$ mortality. Deleterious effects caused by these EOs may be due to some of their constituents or the synergistic combination of several compounds. These EOs have a larvicidal effect against the Coenagrionidae family and fungitoxic activity in vitro against species of pathogenic fungi and wood decay (SILVA et al., 2014; SCHINDLER, 2015). Dillapiole, the major constituent of the EO of $P$. gaudichaudianum, is present in other species of the genus, and its insecticidal activity has previously been described (VOLPE et al., 2016). Natural products, such as glycosides extracted from fresh leaves of Nerium indicum (DAI et al., 2011) and fractions of the methanolic extract of seed flour Camellia oleifera (KIJPRAYOON et al., 2014), also caused $P$. canaliculata mortality. Molluscicidal effect of the EO Cymbopogon winterianus against Biomphalaria glabrata (RODRIGUES et al., 2013) and the hexane and ethyl acetate extracts from the aerial parts of Atriplex inflata against Galba truncatula (HAMED et al., 2015) have also been described.

\section{CONCLUSION}

Based on the results obtained, we can conclude that eugenol, as well as the EOs of $O$. americanum and $O$. majorana, have relaxing activity in $P$. canaliculata and can be used for research purposes in this species. The EOs of $H$. ringens and $P$. gaudichaudianum did not promote relaxation, even at high concentrations, and were also not effective as molluscicides at up to $50 \mu \mathrm{L} \mathrm{L}^{-1}$ against this species.

\section{ACKNOWLEDGMENTS}

B. Baldisserotto and B.M. Heinzmann received Conselho Nacional de Desenvolvimento Científico e Tecnológico (CNPq) research fellowships. J.A. Cunha, B. Schindler, and C.G. Pinheiro received Coordenação de Aperfeiçoamento de Pessoal de Nível Superior (CAPES) scholarships.

\section{REFERENCES}

ADAMS, R.P. Identification of essential oil components by gas chromatography/quadrupole mass spectroscopy. Carol Stream: Allured Publishing Corporation, 2009.

AQUILINA, B.; ROBERTS, R. Amethod for inducing muscle relaxation in the abalone, Haliotis iris. Aquaculture, v.190, p.403-408, 2000. Available from: <http://dx.doi.org/10.1016/S0044-8486(00)00410-5>. Accessed: Jan. 20, 2016. doi: 10.1016/S0044-8486(00)00410-5.

CALUMPANG, S.M. etal. Environmental impact of two molluscicidal: niclosamide and metaldehyde in a rice paddy ecosystem. Bulletin of Environmental Contamination and Toxicology, v.55, p.494-501, 1995. Available from: <https://link.springer.com/article/10.1007\% 2FBF00196027>. Accessed: Jan. 13, 2016. doi: 10.1007/BF00196027.

CULLOTY, S.C.; MULCAHY, M.F. An evaluation of anesthetics for Ostrea edulis (L.). Aquaculture, v.107, p.249-252, 1992. Available from: <http://dx.doi.org/10.1016/0044-8486(92)90073-T>. Accessed: Jan. 13, 2016. doi: 10.1016/0044-8486(92)90073-T.

CUNHA, J.A. et al. Essential oils of Cunila galioides and Origanummajorana as anesthetics for Rhamdia quelen: efficacy and effects on ventilation and ionoregulation. Neotropical Ichthyology, v.15, e160076, 2017. Available from: <http:// www.scielo.br/pdf/ni/v15n1/1982-0224-ni-15-01-e160076.pdf>. Accessed: Jul. 04, 2017. doi: 10.1590/1982-0224-20160076.

DAI, L. et al. Molluscicidal activity of cardiac glycosides from Nerium indicum against Pomacea canaliculata and its implications for the mechanisms of toxicity. Environmental Toxicology and Pharmacology, v.32, p.226232, 2011. Available from: <http://dx.doi.org/10.1016/j.etap.2011.05.007>. Accessed: Jan. 13, 2016. doi: 10.1016/j.etap.2011.05.007.

EUROPEAN PHARMACOPOEIA. European directorate for the quality of medicines. Strassbourg, 2007. 6v.

FERREIRA-DA-SILVA, F.W. et al. Effects of 1,8-cineole on electrophysiological parameters of neurons of the rat superior cervical ganglion. Clinical and Experimental Pharmacology and Physiology, v.11, p.1068-1073, 2009. Available from: $<$ https://www. ncbi.nlm.nih.gov/pubmed/19413602>. Accessed: Jan. 14, 2016. doi: 10.1111/j.1440-1681.2009.05188.x.

GARR, A.L. et al. Development of a captive breeding program for the Florida apple snail, Pomacea paludosa: Relaxation and sex ratio recommendations. Aquaculture, v.370, p.166-171, 2012. Available from: $<\mathrm{http}$ //dx.doi.org/10.1016/j.aquaculture.2012.10.015>. Accessed: Jan. 25, 2016. doi: 10.1016/j.aquaculture.2012.10.015.

GOMES, D.P. et al. Water parameters affect anesthesia induced by eugenol in silver catfish, Rhamdia quelen. Aquaculture Research, v.42, p.878-886, 2011. Available from: <http://onlinelibrary.wiley. com/doi/10.1111/j.1365-2109.2011.02864.x/abstract>. Accessed: Jan. 20, 2016. doi: 10.1111/j.1365-2109.2011.02864.x.

GUNARATNE, A.C. et al. Comparative mapping of GABAimmunoreactive neurons in the central nervous systems of nudibranch molluscs. Journal of Comparative Neurology, v.4, n.522, p.794-810, 2014. Available from: <http://onlinelibrary.wiley.com/doi/10.1002/ cne.23446/abstract>. Accessed: Jan. 14, 2016. doi: 10.1002/cne.23446.

HAMED, N. et al. Molluscicidal and larvicidal activities of Atriplex inflata aerial parts against the mollusk Galba truncatula, intermediate host of Fasciola hepatica. Revista do Instituto de Medicina 
Tropical de São Paulo, v.57, p.473-479, 2015. Available from: <http://dx.doi.org/10.1590/S0036-46652015000600003>. Accessed: Jan. 14, 2016. doi: 10.1590/S0036-46652015000600003.

HATAKEYAMA, D.; ITO, E. Distribution and developmental changes in GABA-like immunoreactive neurons in the central nervous system of pond snail, Lymnaea stagnalis. Journal of Comparative Neurology, v.3, n.418, p.310-322, 2000. Available from: <http://onlinelibrary.wiley.com/doi/10.1002/(SICI)10969861(20000313)418:3\%3C310::AID-CNE6\%3E3.0.CO;2-A/ full $>$. Accessed: Jan. 14, 2016. doi: 10.1002/(SICI) 10969861(20000313)418:3<310::AID-CNE6>3.0.CO;2-A.

HAYES, K.A. et al. Insights from an integrated view of the biology of apple snails (Caenogastropoda: Ampullariidae). Malacologia, v.58, n.2, p.245302, 2015. <Available from: http://dx.doi.org/10.4002/040.058.0209>. Accessed: May 11, 2017. doi: 10.4002/040.058.0209.

HELDWEIN, C.G. Isolamento do principal constituinte ativo do óleo essencial de Lippia alba (MILL.) N. E. Brown com potencial anestésico geral e estudo de mecanismo de ação. 2011. 110f. Dissertação (Mestrado em Farmacologia) - Curso de Pós-graduação em Farmacologia, Universidade Federal de Santa Maria, RS.

HELDWEIN, C.G. et al. Linalool from Lippia alba: sedative and anesthetic for silver catfish (Rhamdia quelen). Veterinary Anaesthesia and Analgesia, v.41, p.621-629, 2014. Available from: $<$ http://dx.doi.org/10.1111/vaa.12146>. Accessed: Jan. 25, 2016. doi: $10.1111 /$ vaa.12146.

KIJPRAYOON, S. et al. Molluscicidal activity of Camellia oleifera seed meal. Science Asia, v.40, p.393-399, 2014. Available from: <http://www.scienceasia.org/2014.40.n6/ scias40 393.pdf $>$. Accessed: Jan. 25, 2016. doi: 10.2306/ scienceasia1513-1874.2014.40.393.

NIST/EPA/NIH. Mass spectral library and search/ analysis programs. Hoboken, NJ: J. Willey and Sons, 2010.

PARODI, T.V. et al. The anesthetic efficacy of eugenol and the essential oils of Lippia alba and Aloysia triphylla in post-larvae and sub-adults of Litopenaeus vannamei (Crustacea, Penaeidae). Comparative Biochemistry and Physiology Part C: Toxicology \& Pharmacology, v.155, p.462-468, 2012. Available from: <http:// dx.doi.org/10.1016/j.cbpc.2011.12.003>. Accessed: Jan. 25, 2016. doi: 10.1016/j.cbpc.2011.12.003.

PINHEIRO, C.G. et al. Seasonal variability of the essential oil of Hesperozygis ringens (Benth.) Epling. Brazilian Journal of Biology, v.76, n.1, p.176-184, 2016. Available from: $<$ http://dx.doi. org/10.1590/1519-6984.16314>. Accessed: Jan. 28, 2016. doi: 10.1590/1519-6984.16314.
RODRIGUES, K.A.F. et al. Molluscicidal and larvicidal activities and essential oil composition of Cymbopogon winterianus. Journal Pharmaceutical Biology, v.51, n.10, p.1293-1297, 2013. Available from: <http://dx.doi.org/10.3109/13880209.2013.78953 6>. Accessed: Jan. 28, 2016. doi: 10.3109/13880209.2013.789536.

SCHINDLER, B. Óleo essencial de Piper gaudichaudianum kunth: rendimento, composição química e atividade fungitóxica in vitro. 2015. 100f. Dissertação (Mestrado em Engenharia Florestal) - Curso de Pós-graduação em Engenharia Florestal, Universidade Federal de Santa Maria, RS.

SILVA, D.T. et al. Larvicidal activity of Brazilian plant essential oils against coenagrionidae larvae. Journal of Economic Entomology, v.107, p.1713-1720, 2014. Available from: <https://doi.org/10.1603/ EC13361>. Accessed: Jan. 25, 2016. doi: 10.1603/EC13361.

SILVA, L.L. et al. Anesthetic activity of Brazilian native plants in silver catfish (Rhamdia quelen). Neotropical Ichthyology, v.11, n.2, p.443-451, 2013. Available from: <http://dx.doi.org/10.1590/S167962252013000200014>. Accessed: Jan. 25, 2016. doi: 10.1590/ S1679-62252013000200014.

SILVA, L.L. et al. Anesthetic activity of the essential oil of Ocimum americanum in Rhamdia quelen (Quoy \& Gaimard, 1824) and its effects on stress parameters. Neotropical Ichthyology, v.13, p.715-722, 2015. Available from: <http://dx.doi.org/10.1590/1982-0224-20150012> . Accessed: Jan. 25, 2016. doi: 10.1590/1982-0224-20150012.

SONG, L. et al. Angiostrongylus cantonensis in the vector snails Pomacea canaliculata and Achatina fulica in China: a meta-analysis. Parasitology Research, v.115, n.3, p.913-923, 2015. Available from: $<$ https://link.springer.com/article/10.1007\%2Fs00436-015-4849-5>. Accessed: Jan. 25, 2016. doi: 10.1007/s00436-015-4849-5.

TONG, F.; COATS, J.R. Effects of monoterpenoid insecticides on ${ }^{[3 \mathrm{H}]}-\mathrm{TBOB}$ binding in house fly GABA receptor and ${ }^{36} \mathrm{Cl}-$ uptake in American cockroach ventral nerve cord. Pesticide Biochemistry and Physiology, v.98, n.3, p. 317-324, 2010. Available from: $<$ http://dx.doi.org/10.1016/j.pestbp.2010.07.003>. Accessed: Jan. 28, 2016. doi: 10.1016/j.pestbp.2010.07.003.

VIEIRA, P.R. et al. Chemical composition and antifungal activity of essential oils from Ocimum species. Industrial Crops and Products, v.55, p. 267-271, 2014. Available from: <http://dx.doi.org/10.1016/j. indcrop.2014.02.032>. Accessed: Jan. 28, 2016. doi: 10.1016/j. indcrop.2014.02.032.

WYETH, R.C. et al. 1-Phenoxy-2-propanol is a useful anesthetic for gastropods used in neurophysiology. Journal of Neuroscience Methods, v.176, p.121-128, 2009. Available from: <http://dx.doi. org/10.1016/j.jneumeth.2008.08.028>. Accessed: Jan. 13, 2016. doi: 10.1016/j.jneumeth.2008.08.028. 